\title{
Evaluation of Adiwiyata Program Implementation in SMAN 1 Martapura
}

\author{
Deasy Arisanty, Sifani Lulu Nisfinahari, Siti Misbah, Suci Indah Sari, Yurika Purnama Sari \\ Department of Geography Education \\ Faculty of Teacher Training and Education \\ Universitas Lambung Mangkurat \\ Banjarmasin, Indonesia \\ deasyarisanty@ulm.ac.id
}

\begin{abstract}
Adiwiyata is a program created by the government to shape the character of students to care about the environment. The purpose of this study is to evaluate the implementation of the adiwiyata program at SMAN 1 Martapura and to analyze the obstacles in implementing the adiwiyata program at SMAN 1 Martapura. This study used qualitative analysis. The data was collected using observations, interviews, and documents. The respondent in this study was chairmen of the adiwiyata program. SMAN 1 Martapura became a national level adiwiyata school in 2013. SMAN 1 Martapura became an independent adiwiyata school. The application of the adiwiyata program at SMAN 1 Martapura is on the aspects of policy, curriculum, participatory and infrastructure facilities. The school made policies related to adiwiyata such as making decrees, adiwiyata committee, and green youth. The adiwiyata program is also applied to geography subjects. The school has also made planned environmental protection and management activities for students and teachers. Management of school infrastructure included the management of classrooms, school yard, and school canteens. The obstacle in implementing the adiwiyata schools at SMAN 1 Martapura are the school policy and integration in the curriculum. The school has not made the adiwiyata program as a priority program. In addition, not all teachers applied local environmental issues as a source of learning.
\end{abstract}

\section{Keywords - adiwiyata program; implementation; evaluation}

\section{INTRODUCTION}

This Rapid development in various sectors such as industry, agriculture, fisheries, livestock, plantations, tourism, health, mining, housing, trade, and transportation has affected environmental sustainability. Environmental degradation such as floods, landslides, erosion, decreasing water quality, and decreasing water discharge has occurred as a result of development that does not pay attention to environmental sustainability [1]. Efforts to overcome the damage done by humans are changing human behavior [2].

Environmental education is a government effort to overcome environmental damage and reduce more severe environmental damage. Environmental education is one of the determinants of success in environmental management. Environmental education is an effort made by the government to provide knowledge about the environment among students. The assumption is that increasing environmental awareness will reduce future environmental damage [1], [3-6].
Efforts to accelerate the development of Environmental Education, especially in formal education, on February 21, 2006, the Ministry of Environment and the Ministry of Education and Culture launched the adiwiyata program. The adiwiyata program aims to encourage and establish a caring and environmental culture school that can participate and implement environmental preservation and sustainable development efforts to get the benefit of present and future generations. The adiwiyata program is a program created by the government to reduce environmental damage. The adiwiyata program is a form of government commitment to environmental management and environmental protection through education. The adiwiyata program encourages the creation of knowledge and awareness of school citizens through educative, participatory and sustainable principles [1], [7] [8].

The adiwiyata program aims to create school citizens responsibility for environmental protecting through good school governance to support sustainable development. The basic principle held by the adiwiyata program is participation, where all components play an active and continuing role, where the program is carried out continuously [9].

The adiwiyata program also aims to create a caring and cultured school that is carried out in stages from the district/city, provincial and national levels. Through this program, students are taught from an early age to be caring and cultured and to have a character of environment love. Adiwiyata School is characterized by a clean, shady, efficient school in the use of paper, water, and electricity. From 2006 to 2016 the number of adiwiyata schools throughout Indonesia is as many as 7,278 schools that spread throughout all provinces in Indonesia from public schools, vocational schools, and madrasas. Some adiwiyata schools get ASEAN level awards as environmentally friendly schools (ASEAN Eco School Award) [10].

One concept in adiwiyata schools is waste management. The program in waste management is zero waste. Zero waste is the use of plastic waste by melting plastic waste into plastic seeds. The use of other plastic waste is to reuse plastic waste into useful items such as innovative, creative, attractive and selling goods [11]. 
An environmentally friendly adiwiyata school is applying the $3 R$ concept. The $3 R$ concept is reduced, reuse and recycle. Reduce is an effort to reduce the use of plastic waste. Reuse is using repetitive items. Recycle is the act of making a new item from garbage by changing the chemical and physical content of the goods [12].

The participation of the school community in implementing the adiwiyata program in schools is an act of caring and awareness of the school environment. The role of the principal is as the originator of the main idea, a policy maker who is proenvironment, fosters a sense of trust capable of gaining achievements and becomes a role model for all school members. The role of the lesson teacher and teacher of environmental education is the main person in charge of delivering values, skills, and knowledge regarding environmental material - the role of students, namely as students, is obliged to implement regulations or policies that have been determined by the school [13].

SMAN 1 Matapura received the first rank of adiwiyata schools in 2011 at the district level. The school received an adiwiyata rank at the provincial level in 2012. The school reached the national level in 2013. The school has become an independent adiwiyata school in 2015. The implementation of the adiwiyata program in schools faces various obstacles and challenges. The role of all school members is very important in implementing the adiwiyata schools. Based on the background, the purpose of this study is to evaluate the application of the adiwiyata program at SMAN 1 Martapura and analyze the obstacles in implementing the adiwiyata program at SMAN 1 Martapura.

\section{METHOD}

This study used qualitative research. The secondary data was obtained through observation, interviews, and documentation. The interview activity was conducted on $26-28$ September 2018 with the respondent being the person in charge of the adiwiyata program. The observations were made to observe the adiwiyata implementation in school by students, and by teachers, and school facility. The document used in this study was syllabi. The data analysis of the group was data grouping, data reduction, data display, and conclusion drawing [14].

\section{RESUlT AND DISCUSSION}

Before The application of the adiwiyata program at SMAN 1 Martapura is in the policy aspect. The policy aspect includes the making of a decree related to the adiwiyata program, the organizational structure to implement the adiwiyata program, and the green youth. Green youth is one of the programs integrated into the student council. Green youth activities are the management of fish ponds, school gardens, and entrepreneurship programs. The field of entrepreneurship trains students to innovate processing materials or make handicrafts using the special characteristics of the school environment. One of the examples is students use coconut waste water in the coconut seller market where the water can still be used, then work with the seller of coconut purchased at a price cheap, made into beverage products like Choco Blend. The product sells every day with a $100 \%$ profit.

The school also has a waste bank. Based on the interview with the respondent of this study who is the head of the adiwiyata program. The obtained information is that "The waste bank program is running in this school, and the management continues because the core of the waste bank program is how to manage waste so that it has economic value. Schools work together with outside parties or third parties to make waste more valuable independently". This school has carried out a collaboration with a collection of waste banks. The school has a balance at the Sekumpul Waste Bank. This school produces a volume of garbage of $134.55 \mathrm{~kg} / \mathrm{day}$. The volume of garbage transported is $34.55 \mathrm{~kg} /$ day from $134.55 \mathrm{~kg}$ because $30 \mathrm{~kg}$ is handled by the waste bank, $41.5 \mathrm{~kg}$ is handled by composting, and $20 \mathrm{~kg}$ is handled by $3 \mathrm{R}$. The Capacity of Temporary Waste Disposal (TPS) at SMAN 1 Martapura is 6 $\mathrm{m}^{3}$.

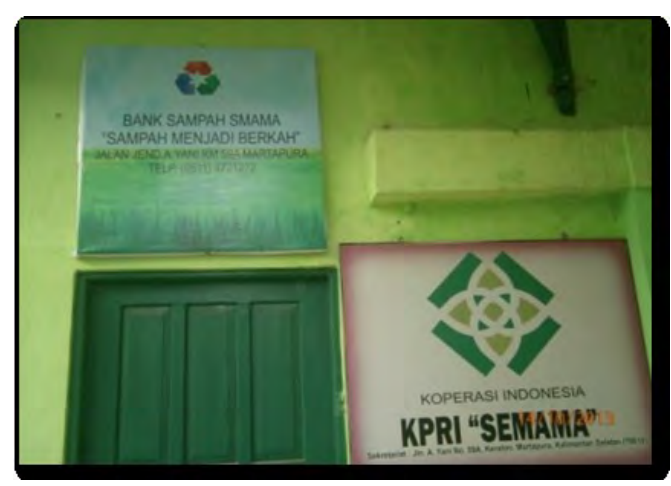

Fig. 1. Waste bank in SMAN 1 Martapura

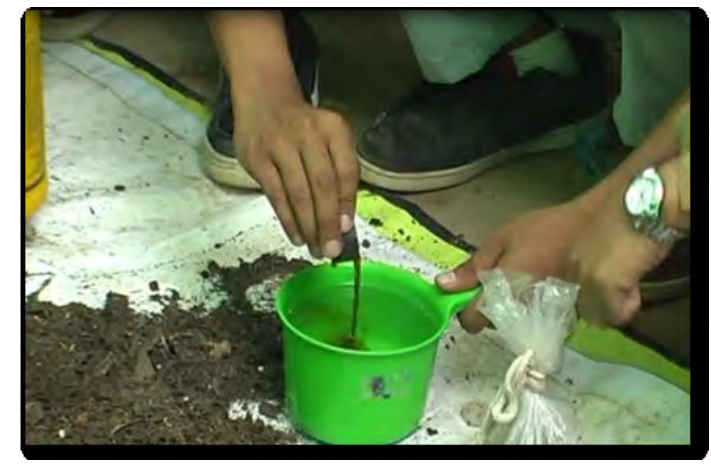

Fig. 2. Composting

The school has carried out planned environmental protection and management activities for the residents of the School. These activities included picking class cleanings, Friday clean, class decorating competitions, maintaining the garden of each class, Friday clean teachers and workshops, social services in the school environment, 1 minute movement to pick up trash, canteen cleanliness, cleanliness at the beginning learning, community service at work, greenhouse working group, school garden working group, composting working group, and nature lover team. Regular environmental cleaning programs are carried out by the school. The respondent revealed that "The clean activity of the school environment is carried out after morning exercise around 20-30 minutes, and clean Friday is for only 15 minutes". The school 
also has bio-pores and infiltration wells. The number of biopores that have been made in this school is 33. The number of infiltration wells is four pieces. The school has also implemented an adiwiyata program into the school curriculum especially for geography subject.

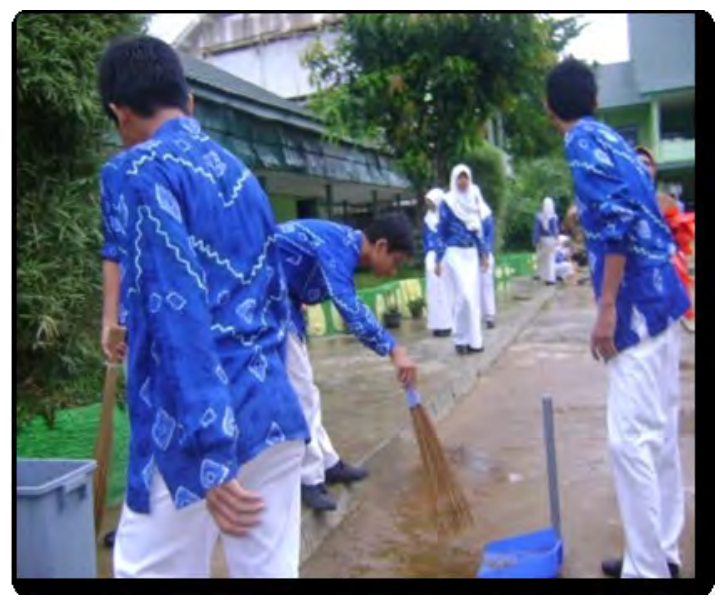

Fig. 3. Clean Friday activity

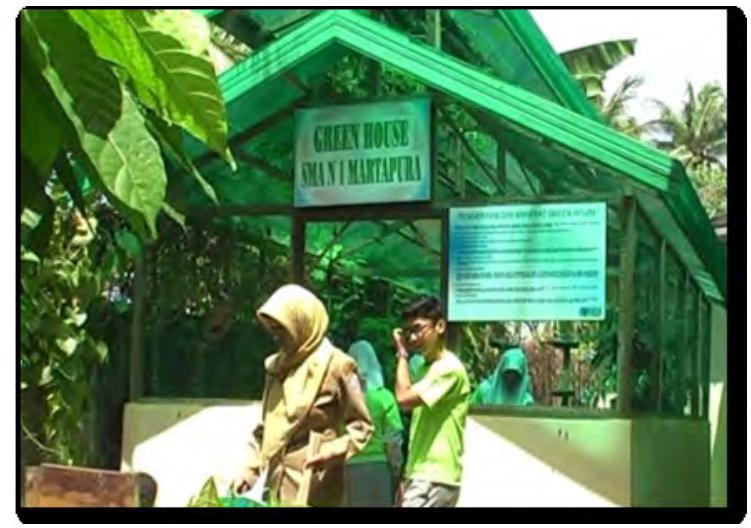

Fig. 4. Green house

Management of school facilities and infrastructure has been carried out by the school. The activities are classroom management. The classroom is arranged by ventilation to have good light and air circulation. Other activities are maintenance and regulation of shade trees and reforestation and using paving blocks on the school yard. Schools also have healthy canteens. Healthy canteen is a canteen that does not sell food/beverages containing preservatives, coloring, flavorings that are not by health standards. The canteen also does not sell contaminated food and expires. In addition, the food in the canteen is not wrapped with environmentally unfriendly packaged foods, such as plastic, and aluminum foil.

The adiwiyata program has benefited all components in the school. The environment will be cleaner, and its sustainability will be maintained. The school also earns money from garbage. The adiwiyata program has also improved the students' skills for solving environmental problems. The application of adiwiyata turns out to be related to the formation of knowledge, attitudes, and actions among students. The implementation of the Adiwiyata program has to do with sustainable development those benefits every stakeholder participating in the activity [3], [6], [15].
Success in implementing the adiwiyata program also depends on student care. The higher the students 'perceptions of the adiwiyata program causes the higher the students' care in environmental management. The level of students' knowledge of the management of the school environment also determines the success of the adiwiyata program. The higher the student's knowledge causes the higher the perception of the adiwiyata program [16].

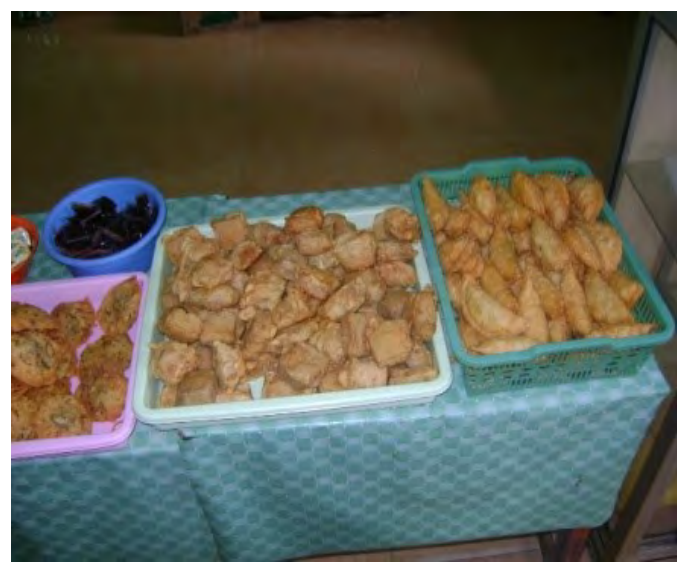

Fig. 5. Healthy canteen

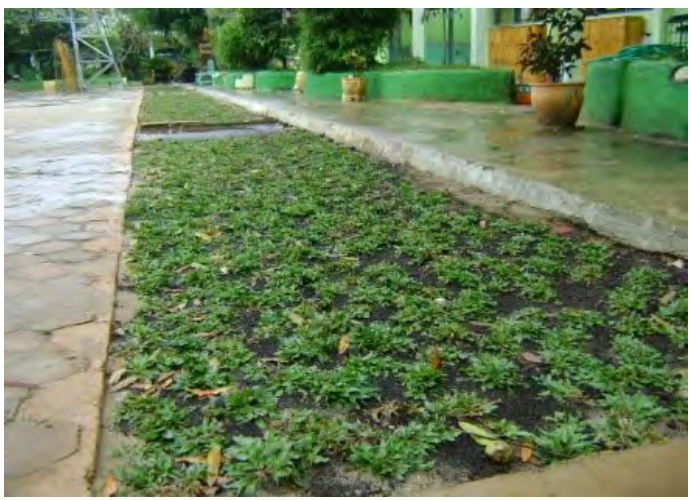

Fig. 6. Schools using block paving

The obstacles faced by schools related to the adiwiyata program include school policies that do not make the adiwiyata program a priority scale and not all teachers integrate the local issues regarding the environment as a part in the teaching and learning activities. As revealed by the head of the adiwiyata program, "The constraints in adiwiyata activities are policies. First, the policy of the principal will be a priority scale. Second, not all teachers integrate local issues as learning materials. One of the goals of the adiwiyata program is in learning by conducting environmental studies such as garbage and rainwater. The problem is what should be integrated into learning, and teachers use a lot of global issues so that learning is not included in students' understanding, what we want is action, learning not only in the classroom but also outside. There is one of the subjects of Prawira that takes action in learning outside the classroom, refers to business such as how to cultivate fish, familiarize students to make aquariums in each class". 


\section{CONCLUSION}

SMAN 1 Martapura is a school that has successfully implemented the adiwiyata program. The programs that have been implemented in this school are green adolescents, the use of waste for sale at waste banks, composting, waste management into $3 \mathrm{R}$, reforestation, maintaining the cleanliness of the school environment through clean Friday programs, biopores making and infiltration wells, green house, implementation in the curriculum and healthy canteen. The constraints in implementing the program are school policies that do not prioritize adiwiyata programs and the teachers who do not make local issues the main issue in classroom learning.

\section{REFERENCES}

[1] Y. D. Rahmah, S. S. Indradi, Riyanto, "Implementasi program sekolah adiwiyata (studi pada SDN Manukan Kulon III/540 Kota Surabaya,' Jurnal Administrasi Publik (JAP), vol. 2, no.4, pp. 753-757, 2014.

[2] Y. Dasrita, Z. Saam, B. Amin, Y. I. Siregar, "Kesadaran lingkungan siswa sekolah Adiwiyata," Dinamika Lingkungan Indonesia, vol. 1, pp. 61- 64, 2016.

[3] R. D. Iswari, S. W. Utomo, "Evaluasi penerapan program Adiwiyata untuk membentuk perilaku peduli lingkungan di kalangan siswa (kasus: SMA Negeri 9 Tangerang Selatan dan MA Negeri 1 Serpong)," Jurnal Ilmu Lingkungan, vol. 15, no.1, pp. 35-41, 2017.

[1] R. B. Ramdhani, "Implementasi program adiwiyata dalam pengelolaan lingkungan sekolah di SMPN 3 Sukabumi,", 2017. [Online]. Available:ejournal.upi.edu/index.php/pips/article/download/4711/3283

[2] E. Landriany, "Implementasi kebijakan adiwiyata dalam upaya mewujudkan pendidikan lingkungan hidup di SMA Kota Malang," Jurnal Kebijakan dan Pengembangan Pendidikan, vol.2, no.2, pp. 82-88, [3] 2014.
[4] G. Aulia, "Partisipasi stakeholder dalam pelaksanaan program adiwiyata di SMP Negeri 4 Bojonegoro," Kebijakan dan Manajemen Publik, vol. 4, no.3, 2016

[5] M. Desfandi, "Mewujudkan masyarakat berkarakter peduli lingkungan melalui program adiwiyata," SOSIO DIDAKTIKA: Social Science Education Journal, vol. 2, no.1, pp. 31-37, 2014.

[6] R. Sulistyowati, D. Slameto, Y. Dwikurnaningsih, "Pengembangan model pembinaan sekolah imbas adiwiyata berbasis partisipasi," Jurnal Manajemen Pendidikan, vol. 4, no. 1, pp. 97-108, 2017.

[7] Kementerian Lingkungan Hidup, Panduan Adiwiyata 2012. Jakarta, 2012.

[8] Kementerian Lingkungan Hidup dan Kehutanan, Buku Panduan Puncak Acara Peringatan Hari Lingkungan Hidup 2017 dan Landmark Hutan Indonesia. Jakarta, 2017. [Online] Available:http://www.menlhk.go.id.

[9] W. P. Lisdiana, S. Nurrohmah, "Pengelolaan limbah plastik di lingkungan sekolah adiwiyata," Prosiding Seminar Nasional Inovasi IPTEKS Perguruan Tinggi untuk Meningkatkan Kesejahteraan Masyarakat, 2016

[10] N. Hidayati, T. Taruna, H. Purnaweni, "Perilaku warga sek] $\backslash=$ olah dalam implementasi adiwiyata di SMK Negeri 2 Semarang," Jurnal Gea, vol. 14, no.1, 2014.

[11] O. E. Paparang, "Peran serta warga sekolah dalam melaksanakan program adiwiyata di SMA Negeri 9 Lempake Samarinda," 2017. [Online]. Available: ejournal.an.fisip-unmul.ac.id.

[12] A. Fatchan, Metode penelitian kuali-tatif (pendekatan etnografi dan etnometo-dologi untuk penelitian ilmu-ilmu sosial). Yogyakarta: Ombak Publisher, 2015.

[13] D. Arisanty, A. Akhla, H. Aperiani, "Implementation of adiwiyata program in MAN 2 Banjarmasin," Proceeding of ISSHE Conference. Universitas Pendidikan Indonesia, 2018.

[14] Sumarlin, R. Rachmawati, Suratman, "Persepsi dan kepedulian siswa terhadap pengelolaan lingkungan sekolah melalui program adiwiyata," Majalah Geografi Indonesia, vol. 27, no. 1, pp. 38-55, 2013. 